\title{
Nielsen v. Preap / 5th grade grammar v. linguistics / Mass imprisonment v. human rights
}

\author{
Elizabeth Coppock*
}

\begin{abstract}
In the Supreme Court case Nielsen v. Preap, ignorance about syntax and semantics led to tragic consequences. The ACLU lawyer defending thousands of non-citizens from being rounded up and put into prison indefinitely by ICE let it come across that her argument rested on the false premise that adverbs can modify nouns. The textualists claimed victory, even though the humane reading of the text was the literal one in this case. The final decision rested crucially on this error on her part, and was buffered by a misunderstanding about how definite descriptions work. The dissent failed to articulate a convincing rebuttal, making spurious reference to passive voice. This case clearly shows how staggeringly consequential linguistic knowledge can be.
\end{abstract}

Keywords. language and law; legal linguistics; semantics, temporal adverbials, passive participles, syntactic categories, definite descriptions

1, Introduction. Nielsen v. Preap was heard in the Supreme Court in October 2018. (I happened to be teaching a course on language and law at the time.) "Nielsen" refers to US Secretary of Homeland Security Kirsten Nielsen, a Trump appointee; "Preap" (first name "Mony") is a particular immigrant to the United States. In this story, the Trump administration, represented by Kiersten Nielsen, is opposed to Mony Preap and thousands of immigrants like him. Likewise, fifth grade grammar is opposed to linguistics, and mass imprisonment is opposed to human rights.

Mony Preap was born in around 1977 in a refugee camp to Cambodian parents who were escaping the Khmer Rouge, so he is stateless, and therefore cannot be deported. In 1981 he started living lawfully in the United States. Some years later he served a jail sentence for possession of marijuana, ending in 2006. In 2013 he was taken into federal custody, where he has remained ever since. In 2018 he was represented in the Supreme Court by the ACLU in this Supreme Court case, Nielsen v. Preap.

The questions taken up in this case were 1) Was Mony Preap lawfully detained in 2013 ? and 2) Can he be released now? The statute under which she was taken into custody is 8 US Code Sec. 1226 (c). Paragraph 1 of this statute reads as follows (and note that by "alien" what is meant is a person who is not a citizen or national of the United States, a very broad category that includes even green card holders):

The Attorney General shall take into custody any alien who:

a) is inadmissible by reason of having committed any offense covered in section $1182(a)(2)$ of this title,

b) is deportable by reason of having committed any offense covered in section 1227(a)(2)(A)(ii), (A)(iii), (B), (C), or (D) of this title,

\footnotetext{
* Thanks to Jill Anderson, Kyle Brennan-Marquez and the participants in the Workshop on Statutory interpretation at LSA 2021, especially Larry Horn and Neal Goldfarb, for helpful discussion. Students in my Boston University course on language and law were also subjected to this material, and I thank them for working through it with me. Author: Elizabeth Coppock, Boston University (ecoppock@bu.edu)
} 
c) is deportable under section $1227(\mathrm{a})(2)(\mathrm{A})(\mathrm{i})$ of this title on the basis of an offense for which the alien has been sentenced to a term of imprisonment of at least 1 year, or

d) is inadmissible under section 1182(a)(3)(B) of this title or deportable under section 1227(a)(4)(B) of this title,

when the alien is released, without regard to whether the alien is released on parole, supervised release, or probation, and without regard to whether the alien may be arrested or imprisoned again for the same offense.

We can compress this into the following:

\section{(1) Paragraph 1 (abridged)}

The Attorney General shall take into custody any alien who meets any of the criteria (a)-(d) when the alien is released.

What does "released" mean? It's about the custody that the non-citizen was in before, as a consequence of having been judged guilty of some prior offense. This presupposition is satisfied in the case that condition (c) "is deportable on the basis of an offense for which the alien, has been sentenced to a term of imprisonment of at least one year" is met. In this case, it would be when the non-citizen is released from that term of imprisonment. It's not clear what to do about cases involving an individual who needs one of criteria (a)-(d) but was never previously incarcerated. The lawyer for the Trump administration, Zachary Tripp, said when pressed on this question by Justice Sotomayor, that "in the overwhelming majority of applications, ... there's going to have been some prior criminal custody," and that "that's really the paradigm of the statute." There seems to be a bit of a presupposition failure there, but I will not be focusing on that particular interesting issue in the interpretation of this statute.

That was Paragraph 1. Paragraph 2 reads roughly as follows:

\section{(2) Paragraph 2 (abridged)}

The Attorney General may release an alien described in Paragraph 1, only if the Attorney General decides the release of the alien from custody is necessary to provide protection to witness or potential witness...

So Paragraph 1 says, "the government shall take into custody any alien who (a)-(d) when the alien he is released." Paragraph 2 says that an alien "described in Paragraph 1" may be released only for witness protection purposes. It is worth noting that although the Trump administration pressed for the most draconian interpretation of this statute possible, the law dates back to 1996, under the Clinton administration, and remains in force even now that a new administration has taken office. Let us now consider how this law applies to Mony Preap.

2. On the meaning of "when". Preap's jail sentence for possession of marijuana ended in 2006. He was taken into federal custody in 2013, and there's a seven-year gap between 2006 and 2013. So arguably, this is not "when". During the oral arguments, Justice Alito said to Cecila Wang:

we have to decide whether "when the alien is released" means, as you say, as the Ninth Circuit said, immediately, within 48 hours, within some reasonable period, or after the alien is released. In simple terms, that's the question before us, right? 
The core of the argument that ACLU lawyer Cecilia Wang made before the Supreme Court is that it means "immediately". Reasonable people can disagree about what constitutes "when" is it the same day? the same week? same month? But seven years later, is not "when". "When" implies simultaneity at some reasonable level of granularity. So Preap should not have been detained in the first place. Furthermore, he is not "described in Paragraph 1", so Paragraph 2 does not prevent the government from releasing him now. Moreover, he should be released now.

Alito pointed out that "A shall happen when B" could in principle be paraphrased as either "A shall happen (more or less) at the same time as B" or "A shall happen at any point during the period that B holds true". What was not pointed out during the oral arguments is that the difference depends on whether B is eventive (see for example Kamp \& Reyle 1993; 656). If I say, "You shall wave at me when I arrive", you have not fulfilled your duties by waving at me three days after I have arrived. But if I say "You shall wave at me when I am at the beach", then as long as I am on the beach when you wave at me, then you have fulfilled your obligation to me. Arriving is an event. Being on the beach is a state. So it makes a difference whether B is an event or a state what temporal relation should hold between A and B in a sentence of the form "A shall happen when B". So in the case of "when the alien is released", the question has to do with whether "the alien is released" describes an event or a state.

It is tempting to locate the ambiguity in the word "when" (Ms. Wang says, " "when' connotes immediacy; that's the primary dictionary definition"), but the word "released" is the only reasonable source of potential ambiguity, as far as I can see. This is the passive form of the verb "release", and such passive participles can be used either as adjectives or verbs. A word like "enlightened", as in "He is very enlightened" contains a passive participle that is used as an adjective. "Very" only modifies adjectives. Here "enlightened" describes a state of enlightenment. If we read "released" as an adjective, then the "when" clause can be rephrased as "when the alien is in a state of release (or 'releasement')". If we read it as a verb, then it means "when the release takes place"; it describes a single event, or happening. This choice state or event - determines what temporal relation holds between A and B. If B is a state, then A can happen any time during B. If $B$ is an event, then "A must happen when B" means that A must happen at the same time that B happens.

Some passive participles, like "enlightened", are much more typically used as adjectives. You can tell that "released" is not normally used as an adjective by trying to make it do things that only adjectives can do, like modify nouns. It makes sense to talk about "an enlightened person", but not "a released person"; I would rather say "a free person". It is also odd to ask, "How long have you been released?"; I would rather say "How long have you been out of jail?" So a construal of "released" as a verbal participle is far more likely.

If it is construed as a verbal participle, then the "when" clause describes an event (of release), not a state. That means that the taking into custody is characterized as taking place at the same time as the release. Of course, there is no sharp boundary delineating when two events have occurred at the same time and when they have not, but 7 years is far beyond the zone where there is any doubt. Clearly, arresting Mony Preap now does not constitute arresting him "when [he] is released", on an eventive construal. The Ninth Circuit court agreed with this assessment, concluding that the apprehension should take place "with a reasonable degree of immediacy".

Even the lawyer for the government, Zachary Tripp, agreed that the text is unambiguous 
in this respect, at least for some of his purposes. In response to a question from Justice Sotomayor, he said that the statute conveys an "urgency" to take these individuals into custody as soon as possible.

Tripp argued, in effect, that the statute was written imprecisely. But the literal interpretation is not "when or as soon as possible thereafter"; it's just "when". During the hearings, Kavenaugh presumed that Wang was asking the court to read in "immediately" to the statute, adding this extra bit of meaning. But that bit is already part of the ordinary meaning of the statute; it's not being added. On the contrary, the government (represented by Tripp) wants the court to read in "or as soon as possible thereafter". It's the government who asked the court to read something into the statute that isn't there. The government asked the Supreme Court to give them authority beyond what is written in the statute to go and round people up and deny them bond hearings.

Maybe Congress even wanted that in 1996 when the statute was written, but they didn't ask for it in this particular statute. It is not impossible to imagine Congress did want that in 1996. As Justice Kavenaugh pointed out, “what was going through Congress's minds in 1996 was harshness"; Congress did indeed want more people incarcerated. But it is also quite plausible that Congress did not intend for this law to lead to a massive hunt for any immigrant with any criminal background whatsoever, no matter how far in the past. The ACLU lawyer Cecilia Wang argued that the restriction with the "when" clause was intended to focus the Department of Homeland Security's resources. Justice Sotomayor pointed out that the "transition rules" that Congress enacted at the same time would have been superfluous if it had been possible for the government to comply with the law by waiting as long as they wanted to apprehend the non-US citizen.

There are cases where it is justifiable to read in "or as soon as possible thereafter". One example brought up by Justice Breyer was the case where a government misses the deadline for a bond hearing. In that case, even if the government misses the deadline, the person in question still has a right to the bond hearing. So in this case, it does make sense to read in "or as soon as possible thereafter". Justice Breyer said that he asked himself, "Is this like that case?" and concluded that the answer was no, because here, reading in this extra bit of meaning hurts innocent people, rather than safeguarding their Constitutional rights. Indeed, here, the extra bit of meaning that would be read in would conflict with the Constitution, which affords people like Mony Preap the right to a bond hearing.

3. On "described" and what adverbs modify. So far, so good. But Justice Gorsuch posed the following challenge, addressing Cecilia Wang:

JUSTICE GORSUCH: Okay. You've hinged a lot on the language, and you've told us to ignore what's happened after 1996 and, in response to Justice Sotomayor, went back to that language, "when the alien is released." But, if we're going to focus really carefully on the language, what do we do about the fact that that is an adverbial phrase? And you're asking us to suggest that it modifies the noun "alien" and limits the class of aliens that are involved. "Alien" is a noun. Adverbs don't usually modify nouns. They usually modify verbs. And the verb here is "shall take into custody." So why isn't it that the duty, "shall take into custody," is modified by the adverb, "when the alien is released," okay, and so the government's obligation begins at that moment. We know that's when the "shall take into custody" 
duty starts. But the class of aliens, the who, the noun, has nothing to do with the adverb. Now that's the question my fifth grade grammar teacher would have, all right? And so I pose it to you.

MS. WANG: Well, I think I'm a grammarian too. The reason why, Justice Gorsuch, is that sometimes adverbial phrases do describe a noun, just as they do in this statute. So, first, for all the reasons I've already said. I -

JUSTICE GORSUCH: Usually, they modify the verb.

MS. WANG: I'll - I will -

JUSTICE GORSUCH: So let's start there.

MS. WANG: - I will concede that. Right -

JUSTICE GORSUCH: Why should we - you're asking us to take a rather unusual view of grammar, one I think I'd have to delve pretty deep in the footnotes to find.

MS. WANG: It wouldn't be the -

JUSTICE GORSUCH: So why would I do that?

MS. WANG: It wouldn't be the first time Congress tortured grammar, but JUSTICE GORSUCH: This - this, I won't argue with you about.

MS. WANG: Right. So - so two - two reasons, Justice Gorsuch. For the reasons I've already said, I think it's clear from the structure of the statute and the plain language that Congress meant for people - for - for paragraph (2), to - to describe a subset of people who were taken into custody in paragraph (1). In all of paragraph (1), not omitting the flush language, as - as my friend describes it. The second reason is, yes, it may be uncommon for an adverbial phrase to describe a noun, but it can happen. Let me give you a hypothetical example that - that that tracks this statute. I might tell you in a two-paragraph instruction, number one, harvest the grapes in vineyards $\mathrm{A}, \mathrm{B}$, and $\mathrm{C}$ when they ripen. Paragraph two: Make the wine from the grapes described in paragraph (1). The grapes refer to both the temporal component, I want you to harvest them when they're ripe, not when they're over-ripe, not when they're under-ripe, and it's from those three vineyards.

JUSTICE GORSUCH: I'm not sure I - I mean, I follow the example, but I'm not sure I buy it, and let me tell you why. And it's a neat example. I commend you. Well done.

(Laughter.)

JUSTICE GORSUCH: I think - I think my fifth grade grammar teacher would love this discussion, but I would say to you or I'd challenge you with this, that, again, there you're modifying the verb, when you're supposed 6 to harvest it, okay? And that's the first - the first section. The second section, you're saying, okay, whatever you've harvested, the grapes that we've described that you have harvested. You still have to have harvested them. So it still depends upon the verb 
in that second paragraph, the verb plus the noun as referred to in the second paragraph. So I'm not sure it gets around the problem. Help me out.

MS. WANG: I - I guess, Justice Gorsuch, I think another way to put this is that what the government's referring to as an adverbial phrase could be rephrased as an adjective.

Let's begin by pointing out that Neil Gorsuch is absolutely right that "when" clauses modify verbs (or verb phrases, to be precise). In Cecilia Wang's example, it's the one headed by the verb harvest:

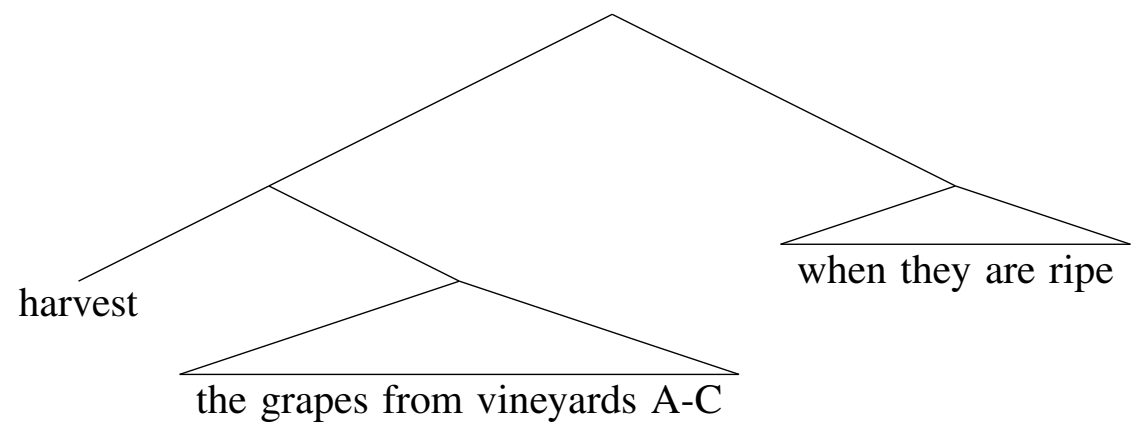

He is also right that in this example "the grapes described in Paragraph 1" are the grapes that were harvested, so the content contributed by the verb goes into the characterization of the grapes in question. (Moreover, it is the grapes that were harvested when ripe.) This is a key point. If, in the 1996 statute, to be "described in Paragraph 1" was simply to be a non-citizen meeting any of the criteria (a)-(d), as the Trump administration argues, then to be "described in Paragraph 1" in Wang's grapes example should simply be to be a grape from one of the vineyards A-C - not a grape harvested. Thus Gorsuch's observation here actually supports Wang's objectives. It is not just the grapes from the designated vineyards that are "described in Paragraph 1", as the Trump administration's legal team would have to say in order to remain consistent. Rather, it is the grapes that have undergone a process described in Paragraph 1. What this shows, then, is that to be described in Paragraph 1 is to undergo a process depicted in Paragraph 1.

Now the question is what kind of process is described in Paragraph 1. The parse that Gorsuch seems to be arguing for is as follows:

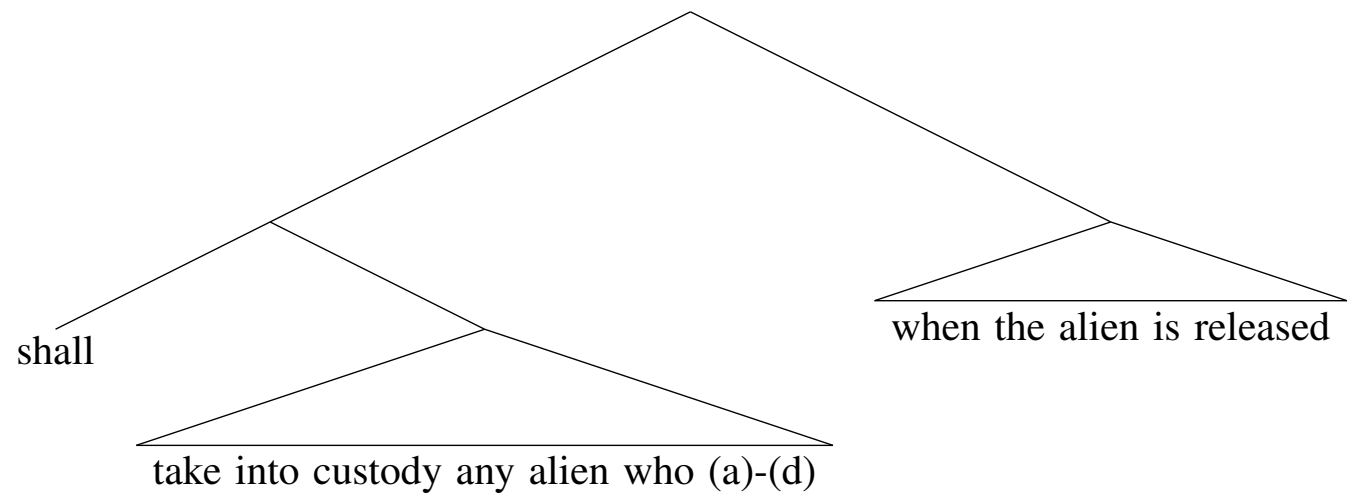

Here "when the alien is released" modifies the phrase headed by shall. Since shall is a verb, and the when-clause is an adverbial phrase, this is syntactically licit, but it doesn't make much 
sense. Gorsuch suggests that the semantic interpretation we would get from this parse is one where "the duty begins" when the alien is released. But there is no precedent for a whenclause specifying the onset of a duty with a strong modal verb like shall. There is no reading of the following sentence, for example, on which students may open their textbooks any time after nine:

(5) Students shall open their textbooks when the clock strikes nine.

The only available reading of this sentence is that the textbook-opening must occur at nine.

Another syntactically viable parse - another one in which the adverbial phrase modifies a verb phrase-is the following:

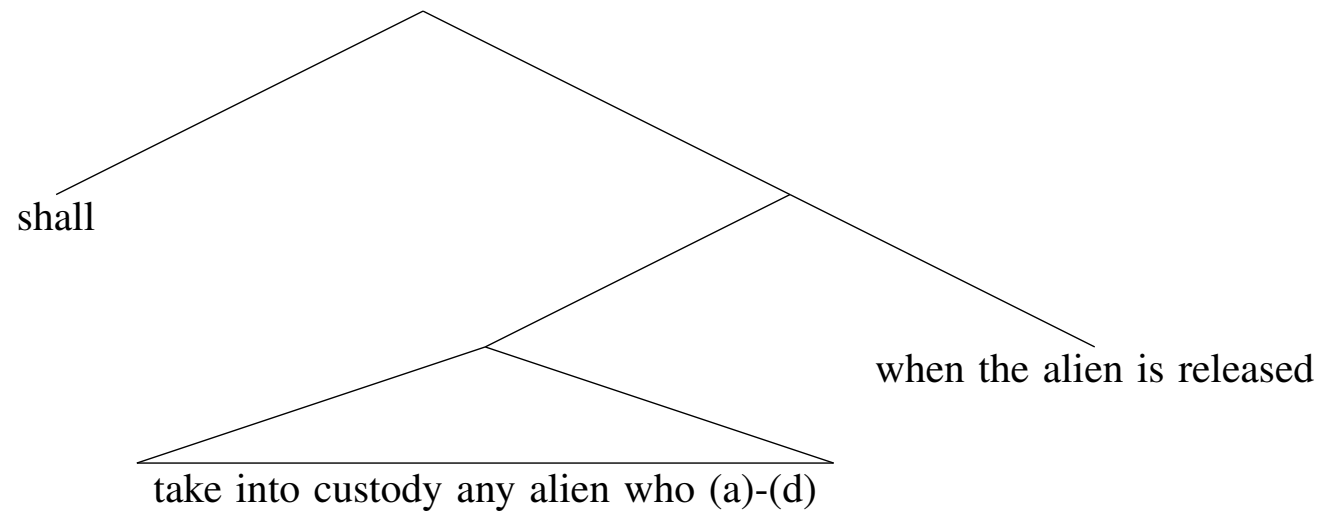

Here, again, the when-clause modifies a verb phrase, but the verb phrase is headed by take rather than shall. With this parse, the duty is to perform a certain action at a certain time. It implies no duties to perform any actions at any other times, in particular any times after the specified time. This is not only the most reasonable parse, it also implies that the government had no obligation to take Mony Preap into custody when they did, and provides a key step in the argument that he should be released now.

At the LSA workshop on statutory interpretation, Neal Goldfarb pointed out another possible parse, where the when-clause modifies (a)-(d):

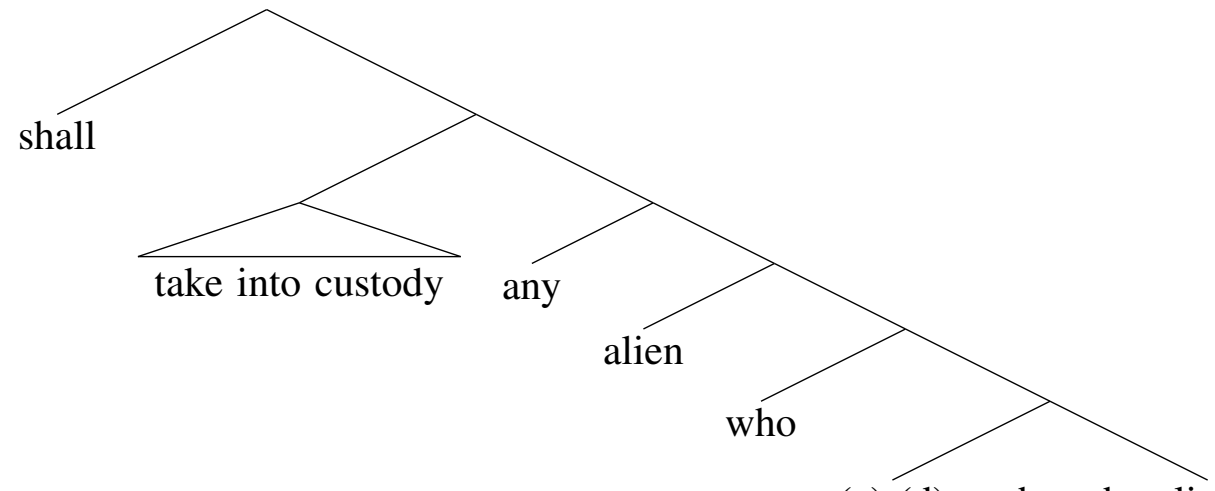

(a)-(d) when the alien is released

This would imply a duty to take into custody anyone whose status as inadmissable or deportable held at the time that they were released. This would not be good for Mony Preap, because he would then be in the class of non-citizens for the government to take into custody. Is it a plausible interpretation? I think not, because (again, as long as the presupposition that there is something to be released from is met) anyone who is inadmissable or deportable for 
any of the specified reasons is so when they are released, so the when clause would not help to further restrict the class of individuals. If the when-clause attaches to the verb, then it specifies the time at which the action should take place. It may also be relevant that neither Gorsuch nor either of the lawyers seems to have considered this parse (nor had I).

In contrast, trying to argue that "when the alien is released" modifies the noun and serves as an adjective is an utterly hopeless enterprise. By making it seem as if her argument rests on the idea that Congress "tortured grammar", Cecilia Wang opened herself up to serious objection, and this may well have lost her the case.

4. How it turned out. The decision was 5-4 against Mony Preap, and thousands like him. This has massive, enormous consequences. People who must now live their lives in terror of ICE include non-citizens who stolen some bus transfers over a decade ago. A person could get rounded up if they live in Washington and state confidently at their green card interview that they smoke marijuana on a regular basis. It applies to innocent children of people convicted of terrorism. ICE could detain you at your home, your job, or at your green card interview. Even green card holders could be imprisoned indefinitely.

Here's the reasoning that the Supreme Court gave in their opinion.

Since an adverb cannot modify a noun, §1226(c)(1)'s adverbial clause "when . . . released" does not modify the noun "alien," which is modified instead by the adjectival clauses appearing in subparagraphs (a)-(d).

Furthermore, they wrote,

The meaning of "described" as it appears in $\$ 1226(c)(2)$ —namely, "to communicate verbally . . . an account of salient identifying features," Webster's Third New International Dictionary... is the relevant definition since the indisputable job of the "descri[ption] in paragraph (1)" is to "identif[y]" for the Secretary which aliens she must arrest immediately "when [they are] released." Yet the "when . . . released" clause could not possibly describe aliens in that sense.

I do not find this assessment indisputable. On the contrary, it seems to me that the role of the description in Paragraph 2 is to identify for the government which non-citizens may be released only for witness protection purposes. Furthermore, the description is not in terms of salient identifying features but rather in terms of a disjunctive list of abstract criteria.

The dissent (signed by Breyer, Ginsburg, Sotomayor, and Kagan) attempted to combat this line of argumentation using following example:

(8) The well-behaved child was taken by a generous couple to see Hamilton.

They write, "That sentence, written in a passive voice, describes the child, not only as well behaved but also as someone taken by a generous couple to see Hamilton." I agree, but I don't think that it's relevant to bring up the passive voice here. As argued above, I think the key point is that to be described in Paragraph 1 is to undergo a process described in Paragraph 1, and this process may be depicted with verbs in active or passive voice. In any case, this was not sufficient to convince them jury of the error of their ways.

In support of their decision, adding insult to injury, the majority wrote: 
Moreover, Congress's use the definite article in 'when the alien is released' indicates that the scope of the word 'alien' has been previously specified in context. Thus the class of people to whom "the alien" refers must be fixed by the predicate offenses identified in subparagraphs (a)-(d).

I don't think they teach this in fifth grade, but definite descriptions can have bound variable uses. This is discussed, for example, by Elbourne (2005), who discusses the following examples:

(9) Mary talked to no senator before the senator was lobbied.

'There is no individual $\mathrm{x}$ such that $\mathrm{x}$ is a senator and Mary talked to $\mathrm{x}$ before $\mathrm{x}$ was lobbied.'

In fact, the very statute under consideration has a use of 'the alien' in exactly this capacity in conditions (c): "is deportable under the law on the basis of an offense for which the alien has been sentenced to a term of imprisonment of at least one year'. Here, 'the alien' occurs middescription. We are not done describing the class of aliens when we have this definite description, 'the alien', serving as a bound variable. So this argument is utterly fallacious in a way that ought to have been recognized.

5. Conclusion. Thousands of people will be rounded up and put into federal prison indefinitely, all because of linguistic ignorance. Cecilia Wang let it come across that her argument rested on the false premise that adverbs can modify nouns, and that was seized upon by the textualists (Alito and Gorsuch) in the decision. The final decision rested crucially on this error on her part, and was buffered by a misunderstanding about how definite descriptions work. The dissent failed to articulate a convincing rebuttal, making spurious reference to passive voice. Ironically, the text was on the side of human rights all along.

What is the way forward? For Mony Preap et al., the only hope is that Congress repeals the law, as far as I can see. Linguistics has already lost to fifth grade grammar in this arena, but we can hope that through greater interaction between linguistics and law, it may prevail in future cases.

\section{References}

Elbourne, Paul. 2005. Situations and individuals. Cabmridge: Cambridge University Press. Kamp, Hans \& Uwe Reyle. 1993. From discourse to logic. Dordrecht: Kluwer Academic Publishers.

Supreme Court of the United States. 2018. Nielsen v. Preap oral arguments. Heritage Reporting Corporation. https://www.supremecourt.gov/oral_arguments/audio/2018/16-1363.

Supreme Court of the United States. 2019. Nielsen v. preap: Decision. Available on supremecourt.gov.https://www.supremecourt.gov/opinions/18pdf/ 16-1363_a86c.pdf. 